Ritrýnd grein birt 31. desember 2020

\title{
Vímuefnaneysla ungmenna skoðuð í ljósi líðanar peirra og tengsla við foreldra
}

\author{
Ragný Póra Guðjohnsen og Ársæll Arnarsson \\ Abstract Um höfunda $\backslash$ About the authors $>$ Heimildir
}

Á unglingsárum takast einstaklingar á við ýmsar breytingar og áskoranir. Góð andleg líðan er forsenda velferðar fólks og pví vekur pað áhyggjur að henni fer hrakandi hjá ungmennum á Vesturlöndum. Áhyggjur beinast einnig að vímuefnaneyslu ungmenna en sífellt koma fram nýjar áskoranir í pví efni. Markmið rannsóknarinnar var að kortleggja andlega líðan og vímuefnaneyslu ungmenna og skoða samband pessara pátta við gæði tengsla við foreldra og kyn. Einnig átti að kanna hjá ungmennum samband andlegrar líðanar, gæða tengsla við foreldra, kyns og efnahagslegs bakgrunns við áfengis- og kannabisneyslu. Notuð voru gögn úr rannsókninni Heilsa og lífskjör skólabarna par sem nemendur í 10. bekk svöruðu spurningalistakönnun. Niðurstöður gáfu til kynna að fjórðungur ungmenna upplifði slök tengsl við foreldra og að pau væru líklegri en hin sem upplifa góð eða mjög góð tengsl, til að líða illa og nota vímuefni. Stúlkur notuðu ekki minna áfengi en drengir pó kannabisneysla peirra væri minni, pær voru líklegri en drengir til að meta tengsl við foreldra slök og ólíklegri til að meta tengslin mjög góð. Tengsl voru einnig milli andlegrar vanlíðanar ungmenna, slakra tengsla við foreldra og verri fjárhagsstöðu fjölskyldu og pess að vera líklegri en pau sem líður betur, hafa betri tengsl og búa við betri fjárhagsstöðu, til að nota bæði áfengi og kannabis. Jafnframt voru tengsl milli vanlíðunar og vímuefnaneyslu óháð tengslum ungmenna við foreldra. Nýta parf snemmbær inngrip pegar einkenni um andlega vanlíðan gera vart við sig. Hvetja parf foreldra til að hlúa að góðum tengslum við börn sín og auka parf pekkingu og hæfni uppeldisaðila til pess að bregðist við vanlíðan ungmenna. Loks parf að tryggja betra aðgengi að geðheilbrigðispjónustu í samfélaginu og draga pannig úr líkum á að andleg vanlíðan á unglingsárum próist á verri veg og ungmenni leiti til bjargráða eins og vímuefna til pess að deyfa hana.

Efnisorð: Ungmenni, andleg vanlíðan, sállíkamleg einkenni, vímuefnaneysla, tengsl við foreldra, HBSC

\section{Inngangur}

Pegar börn nálgast unglingsaldur upplifa margir foreldrar og uppeldisaðilar óöryggi í uppeldishlutverkinu. Áhyggjur beinast að hvernig börnum peirra muni farnast á næstu árum og til framtíðar. Sumir uppalendur kappkosta pví að undirbúa pau sem best, hlúa að vellíðan peirra, samskiptahæfni og heilbrigði. Aðrir upplifa áskoranir í uppeldinu, að peir séu að missa tökin og nái ekki að beina barninu á réttar brautir. Áhyggjur sem snúa að áhættuhegðun á unglingsárum eru ekki úr lausu lofti gripnar. Í samantekt Steinberg (2001), á rannsóknum sem beindu sjónum sínum að ungmennum, kom fram að unglingsárin einkennast almennt af aukinni sókn eftir sjálfstæði og nýjum upplifunum, samskipti við jafningja aukast en foreldrar gegna pó áfram mikilvægu hlutverki í lífi peirra. Ungmennin eru að móta sjálfsvitund sína og leita fyrirmynda og er pessi „leit að sjálfum sér“ 
samofin tengslamyndun og reynslu pessara ára og getur hún skipt miklu fyrir velferð einstaklingsins pegar fram í sækir (Crone og Fuligni, 2020). Á unglingsárum fer andleg vanlíðan barna jafnframt að gera vart við sig eða ágerast (Solmi o.fl., 2021) og horft hefur verið til pess hvort birtingarmynd pessa sé svipuð milli kynja (Deighton o.fl., 2019) en jafnframt hvort kynjamunur sé á vímuefnaneyslu ungmenna (Ingibjörg Eva Pórisdóttir o.fl., 2021).

Markmið pessarar rannsóknar var að kanna andlega líðan og vímuefnaneyslu ungmenna í 10. bekk grunnskóla, ásamt að skoða pessa pætti í tengslum við gæði tengsla við foreldra og kyn. Einnig átti að kanna hvort andleg líðan ungmenna, tengsl við foreldra, kyn og fjárhagsstaða fjölskyldunnar spái fyrir um líkur á að ungmenni hafi reynslu af áfengis- og kannabisneyslu.

\section{Fræðilegur bakgrunnur}

\section{Líðan á unglingsárum}

Um helmingur geðraskana kemur fram hjá einstaklingum á unglingsárum en við 24 ára aldur hafa prjár fjórðu raskana komið fram (Kessler o.fl., 2005). Nokkrar viðamiklar yfirlitsrannsóknir hafa verið gerðar til að kortleggja geðheilbrigði og líðan barna og ungmenna. Í rannsókn Polanczyk og félaga (2015) kom fram að rúmlega 13\% barna og ungmenna um heim allan eru greind með geðraskanir eins og kvíða (6,5\%), punglyndi (2,6\%), ADHD (3,4\%) og aðrar raskanir (5,7\%). İ rannsókn Pitchforth o.fl. (2019) var algengi geðraskana skoðað hjá börnum og ungu fólki (424 ára) í Bretlandi á árabilinu 1995-2014. Niðurstöður sýndu stöðuga aukningu langvarandi geðheilbrigðisvanda. Á Englandi jókst tíðni geðraskana úr 0,8\% í 4,8\% á 19 árum, í Skotlandi úr 2,8\% í 6,5\% á 11 árum og í Wales úr 2,6\% í 4,1\% á 7 árum. Í rannsókn Mojtabai og félaga (2016) var algengi alvarlegra punglyndislota kannað hjá stórum hópi 12-25 ára ungmenna í Bandaríkjunum á tímabilinu 2005 til 2014. Í niðurstöðum kom fram að mun fleiri 12-20 ára ungmenni glímdu við alvarlegar punglyndislotur árið 2014 en árið 2005 og pað prátt fyrir að tekið væri tillit til lýðfræðilegs breytileika og pess hóps sem glímir við fíknivanda. Frekari vísbendingar hafa komið fram um að í hátekjulöndum, meðal annars á Norðurlöndum, glími fleiri börn nú en áður við tilfinningavanda eins og punglyndi og kvíða og að vandinn sé algengari hjá stúlkum en drengjum (Collishaw, 2015). Jafnframt virðast fleiri börn greind með sérparfir í íslensku skólakerfi í samanburði við hin Norðurlöndin (Ramberg o.fl., 2020). Pann varnagla parf pó að slá varðandi samanburð mælinga í mismunandi löndum að hann getur verið flókinn og pví rétt að túlka niðurstöður varfærnislega (Ingibjörg Eva Pórisdóttir o.fl., 2021).

Einnig hefur í pessu sambandi verið bent á að ósértæk andleg vanlíðan hafi aukist, p.e. vanlíðan sem börn og ungmenni tjá en er ekki mæld með greiningarviðmiðum mælinga eins og DSM-5 eða ICD-11 (Baxter o.fl., 2014). Hér má til dæmis nefna sállíkamlegar umkvartanir (e. psychosomatic symptoms) svo sem höfuðverk, magaverk, pirring og kvíða sem gjarnan byrjar á miðstigi grunnskóla en eykst pegar nær dregur unglingsárum og er algengari hjá stúlkum en drengjum (Haugland og Wold, 2001). Ef horft er til niðurstaðna rannsókna má sjá að aukið hlutfall ungmenna á Vesturlöndum greinir frá sállíkamlegum umkvörtunum (Aanesen o.fl., 2017). Aukningin er meiri meðal stúlkna og víða hefur tíðni vikulegra einkenna í pessum hópi aukist um rúmlega $15 \%$ á sîðastliðnum áratug (Inchley o.fl., 2020). Á Íslandi hafa rannsakendur einnig beint sjónum sínum að tíðni sállíkamlegra einkenna og einkenna um vanlíðan sem ekki byggja á greiningarviðmiðum. Í einni slíkri rannsókn kom fram að tíðni daglegrar depurðar skólabarna hafi aukist um priðjung á tímabilinu frá 2006 til 2018 (úr 5,8\% í 7,6\%) (Ársæll Arnarsson, 2019).

Bent hefur verið á að mikilvægt sé að bregðast ekki síður við ósértækum birtingarmyndum af andlegri vanlíðan (Ravens-Sieberer o.fl., 2009). Einkenni eins og sállíkamlegar umkvartanir geta verið fyrirboði alvarlegri einkenna síðar (Kessler o.fl., 2003) og vaxandi pjónustuparfa í heilbrigðiskerfinu, par með parfar fyrir lyfjagjöf snemma á ævinni (Holstein o.fl., 2015). Snemmbært inngrip í upphafi unglingsáranna er á hinn bóginn einn peirra pátta sem talinn er geta fyrirbyggt alvarlegri vanda 
pegar fram í sækir (Graber og Saczawa, 2014).

Slæm geðheilsa dregur úr velferð ungmenna á margvíslegan hátt, m.a. líkum á að ljúka námi og fá atvinnu (Veldman o.fl., 2015) og pví að vera í farsælum félagslegum samskiptum (Mojtabai o.fl., 2017). Auk pess auka geðraskanir líkur á sjálfsvígstilraunum hjá fólki og á pað sérstaklega við hjá aldurshópnum 12 til 26 ára (Gili o.fl., 2019).

Pá hafa rannsóknir gefið til kynna að börn og ungmenni upplifi, ekki sîður en fullorðnir, stimplun tengda vanlíðan og geðröskunum (Milburn o.fl., 2017). Pau mæta fordómum og staðalímyndir eru dregnar upp í tengslum við líðan peirra. WHO (2017) hefur lagt áherslu á að stimplun sé ein stærsta hindrun pess að leitað sé viðeigandi meðferðar vegna geðraskana, sér í lagi hjá pjóðum par sem efnahagsleg velsæld er meiri. Рað að ekki sé brugðist við nægilega snemma er jafnframt talin ein af ástæðum pess að geðheilsuvandi á unglingsárum próast í að verða fjölpættur og langvarandi (DeLuca, 2020).

Vegna vaxandi geðheilbrigðisvanda ungmenna hefur WHO (2017) sett geðheilbrigðismál í forgang og hvatt aðildarríki til pess að stuðla að andlegri vellíðan og góðri geðheilsu peirra með nokkrum lykilaðgerðum. Í fyrsta lagi með samfélagslegum inngripum, svo sem með pví að draga úr fátækt. Í öðru lagi með gagnreyndum forvörnum, til dæmis með fræðslu í skólum. Í priðja lagi með inngripum velferðarkerfa svo sem með pví að veita sálrænan stuðning og auka færni uppeldisaðila og starfsfólks skóla og stofnana til pess að vinna með vanlíðan, hegðunarerfiðleika og annan geðheilsuvanda ungmenna. Pá leggur stofnunin áherslu á að tryggja purfi gott aðgengi að geðheilbrigðispjónustu.

Hér á landi veitir Barna- og unglingageðdeild Landspítala (BUGL) pjónustu til ungmenna vegna geðraskana bæði á göngudeild og bráðadeild. Í apríl 2021 voru 83 börn á biðlista eftir pjónustu BUGL, 432 börn í meðferð og 65 nýjar beiðnir í vinnslu (Landspítali, 2021). Fjöldi barna sem fékk pjónustu göngudeildar BUGL árið 2019 var 845 og komur á deildina pað árið voru samtals 8193. Bráðapjónustu fengu 264 börn með geðrænan vanda árið 2019. Á árunum 2020 og 2021 hefur bráðinnlögnum á Barna- og unglingageðdeild vegna sjálfsvígshugsana barna og ungmenna fjölgað verulega og bent hefur verið á að pessi hópur barna hafi upplifað fjármálakreppuna árið 2008 en í framhaldi hennar tókust margar fjölskyldur á við erfiðleika auk pess sem skorin var niður velferðarpjónusta barna (Gunnhildur Arna Gunnarsdóttir, 2021).

Að íslenskum lögum teljast ungmenni fullorðin við 18 ára aldur og pví skapast eftir pann aldur oft gap í ýmissi velferðarpjónustu (Embætti landlæknis, 2018). Vitund um petta hefur leitt til pess að í Nýja-Sjálandi var ákveðið að framlengja aðgengi að velferðarpjónustu ungs fólks til 24 ára aldurs (Office of the Minister for Social Development, 2016).

\section{Vímuefnaneysla ungmenna}

Með sameiginlegu átaki peirra sem standa að börnum og ungmennum hér á landi tókst á fyrsta tug nýrrar aldar að draga verulega úr áfengisdrykkju ungmenna á grunnskólaaldri frá pví sem áđur tíðkaðist (Álfgeir L. Kristjánsson o.fl., 2016). Á hinn bóginn beinast áhyggjur að aukinni neyslu ýmissa annarra vímuefna, svo sem kannabis (Arnarsson o.fl., 2018), lyfseðilsskyldra lyfja (Gísli Kort Kristófersson o.fl., 2017) og „spice“ sem ungmenni geta veipað (Guðrún Ágústa Ágústsdóttir, 2021).

Neysla vímuefna tvöfaldast síðan pegar ungmenni eru komin á framhaldsskólaaldur (Margrét Lilja Guðmundsdóttir o.fl., 2020) og vímuefnaneysla peirra sem ekki halda áfram námi, eru aðallega í vinnu eða atvinnulaus, er tvöfalt meiri en peirra sem halda áfram námi (Hrefna Pálsdóttir o.fl., 2010). Eftir 18 ára aldur eykst áfengisneysla enn meira og er hlutfall fullorðinna hér á landi sem stunda áhættudrykkju hæst á aldrinum 18-34 ára (Embætti landlæknis, 2021b).

\section{Áhættupættir á unglingsárum}


Á unglingsárum eru ýmsir áhættupættir sem geta aukið líkur bæði á slæmri líðan ungmenna og áhættuhegðun eins og vímuefnaneyslu. Pessir pættir tengjast ýmist einstaklingnum sjálfum eða samspili einstaklingsins við umhverfið, svo sem fjölskyldu, vini, skóla eða samfélagspjónustu (Bronfenbrenner, 2005; Lansford og Banati, 2018).

Áhættupættir sem rannsóknir hafa gefið til kynna að auki líkur á verri andlegri líðan barna og ungmenna eru til dæmis lítill svefn (Woods og Scott, 2016), neikvæð líkamsímynd (Aanesen o.fl., 2017), mikil skjánotkun (Odgers og Jensen, 2020), aukinn prýstingur á langskólanám (Hutchings og Kazmi, 2015), að alast upp við fátækt (Ársæll Arnarsson, 2019; Deighton o.fl., 2019) og vímuefnaneysla (Ottová-Jordan o.fl., 2015).

Áhættupættir fyrir áfengis- og vímuefnaneyslu á unglingsárum eru ýmsir. Glími ungmenni við geðraskanir, einkum kvíðaraskanir og hegðunarvanda, eru pau talin líklegri en pau sem ekki eru greind með geðraskanir til að nota meira áfengi og vímuefni og að glíma við vanda í tengslum við neysluna (Conway o.fl., 2016). Jafnframt getur pað aukið líkur á vímuefnaneyslu að alast upp við fátækt (Manhica o.fl., 2021).

Pættir eins og að búa við vímuefnaneyslu foreldra (Bountress og Chassin, 2015; Conners-Burrow o.fl., 2015) geta aukið líkur bæði á innri og ytri vanda hjá börnum og geðraskanir foreldra eru, vegna skorts á eðlilegri tengslamyndun við barnið, taldar auka líkur á að barnið sjálft prói með sér geðraskanir og vímuefnavanda (Manning og Gregoire, 2009).

Rannsakendur hafa jafnframt beint sjónum sínum að uppeldisháttum foreldra í tengslum við velferð barna til framtíðar (Baumrind, 1991; Sigrún Aðalbjarnardóttir, 2019). Baumrind (1971) og félagar (Maccoby og Martin, 1983) skiptu uppeldisháttum í fjóra flokka sem styðja misvel við velferð og proska barna. Leiðandi uppeldishættir eru taldir styðja best við farsæld barnsins en peir einkennast af góðum tengslum foreldris og barns par sem barnið fær hlýju, stuðning og viðurkenningu, sett eru skýr mörk sem eru útskýrð fyrir barninu og hlustað er eftir sjónarmiðum barnsins. Leiðandi foreldrar koma pannig til móts við sálrænar parfir barns síns sem styður við að barnið tileinki sér heilsteypta sjálfsmynd og sjálfstæði til að takast á við verkefni daglegs lífs, nám og starf, fylgi leiðbeiningum um hegðun, sýni samskiptafærni og seiglu í mótdrægum aðstæðum (Sigrún Aðalbjarnardóttir, 2019; Soenens o.fl., 2017). Pessar aðferðir auka jafnframt líkur á að barnið sæki stuðning til foreldra sinna og tileinki sér leiðsögn peirra pegar eitthvað bjátar á. Skipandi uppeldishættir eru á hinn bóginn einhliða og foreldrar nota boð og bönn en veita ekki hlýju og stuðning. Eru börn pessara foreldra líklegri til að glíma við hegðunarerfiðleika (Ruiz-Hernández o.fl., 2018). Skortur á mörkum og undanlátssemi einkennir eftirláta uppeldishætti og eru peir taldir auka líkur á að ungmenni byrji snemma að nota áfengi (Koning o.fl., 2012). Afskiptalausir uppeldishættir eru barninu síðan skeinuhættastir en pá eru foreldrar ekki til staðar fyrir barn sitt og veita pví ekki pau öruggu tengsl og pann stuðning sem pað parf á að halda. Börn í pannig aðstæðum upplifa oft mikla streitu strax á unga aldri og verða pví líklegri til að eiga við hegðunarvanda að stríða sem jafnframt er áhættupáttur fyrir vímuefnaneyslu strax á unglingsárum (Otten o.fl., 2019). Í pessu sambandi eru börn foreldra sem glíma við fíknivanda til dæmis í sérstaklega viðkvæmri stöðu (Conners-Burrow o.fl., 2015).

Bornstein og Putnick (2018) hafa bent á að í fræðilegri umræðu um uppeldishætti hafi ekki nægilega verið horft til pess tilfinningalega andrúmslofts sem einkennir tengsl og samskipti foreldris og barns. Alist barn upp við örugg tengsl og andrúmsloft par sem foreldrar styðja við proska barna til pess að taka góðar ákvarðanir með margvísleg rök að leiðarljósi, pá sé líklegra að pví farnist vel og pað upplifi síður vanlíðan eða leiðist út í áhættuhegðun (Ainsworth, 1973; Bowlby, 1988). Donovan (2018) hefur á sömu nótum bent á að tengsl foreld ris og barns skipti máli fyrir líkur á vímuefnaneyslu ungmenna, einkum séu samræður sem snúa beint að notkun vímugjafa mikilvægar.

Góð samskipti á heimilinu gegna pannig lykilhlutverki fyrir velferð barnsins og styðja við líkur á betri geðheilsu og almennri velferð og draga úr líkum á vímuefnaneyslu (Moore o.fl., 2018). Flókið fjölskyldumynstur í nútímasamfélagi er á hinn bóginn talið auka álag og líkur á að ungmenni upplifi meiri vanlíðan en ungmenni sem búa með báðum foreldrum (Låftman o.fl., 2014). 
Loks má nefna að einstaklingspættir eins og erfðapættir og umhverfispættir eru gjarnan samofnir áhættupættir eins og komið hefur í ljós hjá börnum sem alast upp við geðraskanir foreldra og vímuefnaneyslu en pau virðast í aukinni hættu á að glíma við vanlíðan og geðraskanir pegar kemur fram á fullorðinsár og að próa með sér vímuefnavanda (Meyers og Dick, 2010).

Í ljósi framangreindrar pekkingar er áhugavert að skoða tengsl íslenskra ungmenna við foreldra sína og mikilvægi peirra fyrir líðan peirra. Einnig hvernig pessir tveir pættir spila saman pegar kemur að vímuefnaneyslu ungmenna. Í pessu skyni eru í rannsókninni settar fram fimm tilgátur. Í fyrsta lagi sú tilgáta að ungmennum sem upplifa lakari tengsl við foreldra líði verr en peim sem upplifa betri tengsl við foreldra (T1). Í öðru lagi sú tilgáta að ungmenni sem upplifa lakari tengsl við foreldra hafi meiri reynslu af vímuefnanotkun en hinir sem upplifa betri tengsl (T2). Í priðja lagi að eftir pví sem ungmennum líður verr (hafa fleiri sállíkamlegar umkvartanir), peim mun líklegri séu pau til að hafa meiri reynslu af vímuefnanotkun óháð tengslum við foreldra sína (T3). Í fjórða lagi sú tilgáta að stúlkur séu líklegri en drengir til að vera í góðum samskiptum við foreldra sína og noti minna af vímuefnum (T4). Í fimmta lagi sú tilgáta að pau ungmenni sem búa við verri fjárhagsstöðu séu líklegri til að hafa meiri reynslu af vímuefnaneyslu (T5).

\section{Аðferð}

Heilsa og lífskjör skólabarna (HBSC) er fjölpjóðleg rannsókn, studd af Alpjóðaheilbrigðismálastofnu ninni (WHO), par sem unglingar í 6., 8. og 10. bekk grunnskóla eru spurðir um ýmsa pætti varðandi heilsu, líðan og félagslegar aðstæður (Inchley o.fl., 2020). Fyrsta fyrirlögnin fór fram veturinn 19831984 og hún hefur síðan verið endurtekin fjórða hvert ár. Frá árinu 2006 hefur pessi rannsókn verið lögð fyrir á Íslandi. Síðasta fyrirlögn var veturinn 2017-2018 og fengust pá svör frá 7159 nemendum. Í pessari greiningu er notast við svör nemenda í 10 . bekk $(\mathrm{N}=2247)$ par sem ekki var spurt um kannabisneyslu meðal yngri pátttakenda.

\section{Framkvæmd}

Áður en gagnasöfnun hófst veturinn 2017-2018 var spurningalistinn sendur, ásamt rannsóknaráætlun, til Persónuverndar og Vísindasiðanefndar Háskóla Íslands. Engar athugasemdir voru gerðar við fyrirhugaða framkvæmd. Að pví loknu voru sömu upplýsingar sendar öllum skólastjórum á Íslandi sem höfðu nemendur í 6., 8. eða 10. bekk og pess óskað að peirra skólar tækju pátt. Síðan var öllum foreldrum og forráðamönnum sent kynningarbréf og peim gefið tækifæri til að hafna pátttöku sinna barna.

Fyrirlagning spurningalistans var með rafrænum hætti. Borð nemenda voru færð í sundur til pess að tryggja að svarendur sæju ekki svör annarra og svo opnaði hver og einn sinn lista á sinni tölvu. Í upphafi var stutt lýsing á rannsókninni ásamt skýrum skilaboðum pess efnis að jafnvel pótt foreldrar peirra og skólayfirvöld hefðu gefið leyfi, pá væri nemendum sjálfum frjálst að neita pátttöku eða sleppa að svara ákveðnum spurningum. Pá var ítrekað að um nafnlausa könnun væri að ræða.

\section{Mælitæki}

Í rannsókninni voru notaðar prjár mælingar HBSC. Styrkur tengsla við foreldra var skoðaður með spurningum um tengsl við líffræðilega foreldra og/eða stjúptengsl ef pau voru fyrir hendi (Ársæll Arnarsson, 2019; Ársæll Arnarsson o.fl., 2020). Pátttakendur voru beðnir um að segja til um hversu auðvelt peir ættu með að tala um pað sem ylli peim áhyggjum við föður sinn, móður sína, stjúpföður eða stjúpmóður. Svarmöguleikarnir voru fimm: 1) Mjög auðvelt, 2) Auðvelt, 3) Erfitt, 4) Mjög erfitt, 5) Á ekki við eða hitti ekki viðkomandi. Svörin við spurningunum voru kóðuð pannig að gildið 1 táknaði slök tengsl og í pann flokk féllu pau ungmenni sem sögðust eiga erfitt eða mjög erfitt með að tala við foreldra sína. Pau ungmenni sem sögðust ekki eiga eða ekki hitta foreldra voru einnig sett í pennan flokk. Pau sem sögðust eiga auðvelt með að tala við foreldra fengu gildið 2 sem táknar góð 
tengsl og ef samskiptin voru mjög auðveld fengu pau gildið 3. Kóðunin var hins vegar aðallega gerð til pess að reikna út samtölu fyrir tengsl við foreldra, p.e. að skoða ekki einungis áhrif eins foreldris heldur tveggja eða fleiri par sem pað átti við. Í peim útreikningi var stuðst við einfalda formúlu Andersen og Dæhlen (2017), par sem gildin frá 1 upp í 3 eru lögð saman og deilt í með tveimur ef um tvo foreldra er að ræða, premur ef foreldrarnir eru prír og fjórum ef ungmennið metur samskipti við föður, móður, stjúpföður og stjúpmóður. Pað pýðir t.d. að ungmenni sem á tvo foreldra og segist vera í góðum tengslum við stjúpföður (gildið 2) og mjög góðum tengslum við móður (gildið 3) fær samtöluna 2,5. Ungmenni sem á prjá foreldra og segist vera í mjög góðum tengslum við móður og stjúpmóður (tvisvar sinnum gildið 3) en slökum tengslum við föður (gildið 1) fær samtöluna 2,3. Ungmenni sem á tvö heimili með tveimur settum af foreldrum og metur t.d. tengsl við föður og stjúpmóður slök (tvisvar sinnum gildið 1) en tengsl við móður og stjúpföður góð (tvisvar sinnum gildið 2) fær samtöluna 1,5.

Lægsta hugsanlega gildið sem hægt var að fá var 1,0 en pað hæsta 3,0. Dreifingin á gildunum var skekkt til hægri, með öðrum orðum, fleiri ungmenni mátu tengsl við foreldra góð en slæm. Samtölur undir 1,6 voru metnar sem merki um slök tengsl við foreldra, á meðan pær sem lentu á milli 1,6 upp í 2,2 voru túlkaðar sem góð tengsl. Allar samtölur yfir 2,2 voru skilgreindar pannig að ungmenni hefði mjög góð tengsl við foreldra sína. Pessi prískipting var síðan skoðuð með tilliti til annarra breyta í rannsókninni, eins og lífsánægju, mats á eigin heilsu og einmanaleika. Í ljós kom að hóparnir prír komu marktækt mismunandi út á peim í samræmi við pað sem ætla mætti, p.e. að peir sem mátu foreldratengslin sem mjög góð komu best út, en peir sem mátu pau slök, komu verst út.

Liðan ungmenna var mæld með átta spurninga mælingu á sállíkamlegum umkvörtunum (e. HBSC-symptom checklist) (RavensSieberer o.fl., 2008) og voru nemendur beðnir um að svara hversu oft síðastliðna sex mánuði peir hefðu fundið fyrir: a) höfuðverkjum, b) magaverkjum, c) bakverkjum, d) depurð, e) pirringi eða skapvonsku, f) kvíða, g) svefnörðugleikum eða h) svima. Svarmöguleikarnir við hverja spurningu voru fimm og voru kóðaðir sem hér segir: Sjaldan eða aldrei=0; Um pað bil mánaðarlega=1; Um pað bil vikulega=2; Oftar en einu sinni í viku=3 og; Hér um bil daglega=4. Pessi svör voru notuð til að búa til nafnbreytu sem gerði greinarmun milli peirra sem höfðu fleiri en tvö einkenni vikulega og hinna sem höfðu færri. Mælingin mælir ekki klínísk einkenni en rannsóknir hafa staðfest réttmæti og áreiðanleika mælingarinnar til pess að mæla geðheilbrigði barna og ungmenna (Gariepy o.fl., 2016) með pví að mæla sálfræðilega pætti sem tengjast líðan, s.s. að vera niðurdreginn og kvíðinn og líkamlega pætti eins og höfuðverk og magaverk (Haugland og Wold, 2001).

Vimuefnanotkun ungmenna í pessari rannsókn var mæld með spurningum um hvort pátttakendur hefðu einhvern tíma á ævinni drukkið áfengi eða notað kannabis. Svarmöguleikarnir voru: 1) aldrei, 2) 1-2 sinnum, 3) 3-5 sinnum, 4) 6-9 sinnum, 5) 10-19 sinnum, 6) 20-29 sinnum eða 7) 30 sinnum eða oftar. Í frekari greiningu gagnanna var svarendum skipt í tvo hópa, p.e. pá sem höfðu aldrei á ævinni neytt pessara efna og pá sem einhvern tíma höfðu gert pað. Í aðhvarfsgreiningum voru pessar breytur notaðar sem jafnbilabreytur pó strangt til tekið sé um raðbreytur að ræða. Í útreikningum var pessum breytum einnig umbreytt í prjár nafnbreytur til að bera saman pá sem höfðu enga reynslu af pessum vímuefnum og hina sem höfðu aðeins prófað áfengi, pá sem höfðu aðeins prófað kannabis og pá sem höfðu reynslu af hvoru tveggja.

Bakgrunnsbreytur í rannsókninni voru tvær. Annars vegar kyn par sem svarmöguleikar við spurningunni „Ég skilgreini kyn mitt sem“, voru stúlka, drengur eða annað. Hins vegar Fjárhagsstaða fjölskyldunnar sem byggði á svari við spurningunni „Hversu gott telur pú fjölskyldu pína hafa pað fjárhagslega?"“ Svarmöguleikar voru kóðaðir á fimm punkta kvarða frá „mjög slæmt“ til „mjög gott“.

\section{Tölfræðileg úrvinnsla}

Tölfræðileg úrvinnsla var framkvæmd með IBM SPSS-tölfræðiforritinu fyrir Windows (útgáfa 24.0). Lýsandi tölfræði var notuð til að lýsa gögnunum, Kí-kvaðrat var notað til reikna mun á hlutföllum og línuleg aðhvarfsgreining til að skoða sambandið milli tengsla við foreldra, sállíkamlegra einkenna og vímuefnaneyslu. 


\section{Niðurstöður}

Alls tóku 2247 nemendur í 10. bekk pátt í könnuninni; 1086 drengir, 1111 stúlkur og 40 sem skilgreindu kyn sitt sem annað. Tafla 1 sýnir hlutfall peirra nemenda í 10. bekk sem sögðust finna fyrir að minnsta kosti tveimur sállíkamlegum einkennum vikulega eða oftar.

Um fjórðungur nemenda upplifði slök tengsl við foreldra eins og sést í Töflu 1. Stúlkur voru líklegri en drengir til að finna fyrir slökum tengslum en nemendur sem skilgreindu kyn sitt sem annað voru pó líklegastir til að meta tengslin slök. Drengir voru sömuleiðis líklegri en stúlkur til pess að meta tengsl við foreldra sem mjög góð en ólíklegust til pess voru pau ungmenni sem skilgreindu kyn sitt sem annað. Pessi munur milli tengsla við foreldra eftir kynjum var tölfræðilega marktækur $X^{2}$ (6, $\mathrm{N}=2245)=76,23, \mathrm{p}<, 001)$. Tafla 1 sýnir einnig hlutfall sállíkamlegra einkenna eftir tengslum við foreldra. Slakari tengsl við foreldra höfðu marktæk tengsl við auknar líkur á að ungmenni upplifi tvö eða fleiri sállíkamleg einkenni vikulega $\left.X^{2}(2, \mathrm{~N}=2208)=184,43, \mathrm{p}<, 001\right)$.

Tafla 1. Hlutfall ungmenna í 10. bekk eftir fjölda sállíkamlegra umkvartana, tengslum við foreldra og kyni $-\%(\mathrm{~N})$.

\begin{tabular}{lllll}
\hline & Slök tengsl & Góð tengsl & Mjög góð tengsl \\
\hline Drengir & $21,7(230)$ & $31,2(331)$ & $47,1(500)$ \\
& $<2$ einkenni & $15,2(115)$ & $31,1(236)$ & $53,7(407)$ \\
& $>2$ einkenni & $38,0(115)$ & $31,4(95)$ & $30,7(93)$ \\
\hline Stúlkur & $29,3(323)$ & $29,5(326)$ & $41,2(455)$ \\
& & $17,8(100)$ & $29,5(166)$ & $52,8(297)$ \\
& $>2$ einkenni & $41,2(223)$ & $29,6(160)$ & $29,2(158)$ \\
\hline Annað & & $36,6(15)$ & $31,7(13)$ & $31,7(13)$ \\
& $<2$ einkenni & $20,2(4)$ & $40,0(8)$ & $40,0(8)$ \\
Alls & $>2$ einkenni & $52,4(11)$ & $23,8(5)$ & $23,8(5)$ \\
& & $25,7(568)$ & $30,4(670)$ & $43,9(968)$ \\
\hline & $>2$ einkenni & $16,3(219)$ & $30,6(410)$ & $53,1(712)$ \\
& $>2$ einkenni & $40,3(349)$ & $30,1(260)$ & $29,6(256)$ \\
\hline
\end{tabular}

Langflest ungmenni í 10. bekk hafa hvorki drukkið áfengi né prófað kannabis eins og Tafla 2 sýnir. Einnig er ljóst að flestir peir sem hafa prófað kannabis hafa líka drukkið áfengi. Stúlkur og drengir hafa prófað áfengi í sama mæli, en stúlkur hafa prófað kannabis í minna mæli en drengir. Aðeins 40 nemendur skilgreindu kyn sitt sem „annað“ og pví er ekki hægt að draga afdráttarlausar ályktanir af peim tölum sem birtast í Töflu 1 um pann hóp. Hins vegar benda pær til pess að pessi hópur sé líklegri til að hafa prófað vímuefni en aðrir. Pessi kynjamunur á vímuefnaneyslu var tölfræðilega marktækur $\left.X^{2}(6, \mathrm{~N}=2245)=61,80, \mathrm{p}<, 001\right)$.

Tafla 2. Hlutfall ungmenna í 10. bekk eftir kyni og pví hvort pau hafa prófað áfengi og/eða kannabis - \% (N).

\begin{tabular}{lccc}
\hline & Drengir & Stúlkur & Annað \\
\hline Hvorki prófað áfengi né kannabis & $71,7(736)$ & $69,4(759)$ & $47,5(19)$ \\
Prófað áfengi en ekki kannabis & $18,3(188)$ & $24,2(265)$ & $12,5(5)$ \\
Prófað kannabis en ekki áfengi & $0,9(9)$ & $0,2(2)$ & $2,5(1)$ \\
Prófað áfengi og kannabis & $9,2(94)$ & $6,1(67)$ & $37,5(15)$ \\
Alls & $100(1027)$ & $100(1093)$ & $100(40)$ \\
\hline
\end{tabular}


Í Töflu 3 má sjá að samband er milli tengslamyndunar við foreldra og pess hvort ungmenni hafi prófað áfengi og/eða kannabis. Ungmenni sem eru í slökum tengslum við foreldra sína eru tvöfalt líklegri til að hafa prófað bæði áfengi og kannabis heldur en pau sem eru í góðum tengslum og prefalt líklegri heldur en pau sem eru í mjög góðum tengslum. Hið sama á við pegar einungis er um áfengisneyslu að ræða pó niðurstöður séu ekki eins afgerandi. Mjög fá hafa prófað kannabis en aldrei áfengi og pví erfitt að fullyrða um pær niðurstöður. Pessi munur milli vímuefnaneyslu eftir tengslum við foreldra var tölfræðilega marktækur X2 $(9, \mathrm{~N}=2247)=123,69 \mathrm{p}<, 001)$.

Tafla 3. Hlutfall ungmenna í 10. bekk eftir pví hvort pau hafa einhvern tíma prófað áfengi og/eða kannabis eftir tengslum við foreldra - \% (N).

\begin{tabular}{llll}
\hline & Slök tengsl & Góð tengsl & Mjög góð tengsl \\
\hline Hvorki prófað áfengi né kannabis & $54,6(310)$ & $71,4(479)$ & $79,5(770)$ \\
Prófað áfengi en ekki kannabis & $29,9(170)$ & $21,3(143)$ & $15,1(146)$ \\
Prófað kannabis en ekki áfengi & $0,9(5)$ & $0,3(2)$ & $0,8(8)$ \\
Prófað áfengi og kannabis & $14,6(83)$ & $7,0(47)$ & $4,6(45)$ \\
Alls & $100(568)$ & $100(671)$ & $100(969)$ \\
\hline
\end{tabular}

Tafla 4 sýnir fylgni milli pess hvernig tengslum ungmennanna við foreldra sína er háttað og pess hversu líkleg ungmennin voru til pess að hafa prófað áfengi og kannabis og hversu oft pað hefur gerst. Par kemur einnig fram að fylgni er milli pess að ungmennin finni fyrir að minnsta kosti tveimur sállíkamlegum einkennum vikulega og pess að nota áfengi og kannabis. Petta er óháð pví hvernig tengslunum við foreldra er háttað. Petta á við bæði um áfengis- og kannabisneyslu, pó að í síðarnefnda tilfellinu séu tölurnar aðeins meira á reiki, enda hafa mun færri ungmenni prófað kannabis.

Tafla 4. Hlutfall ungmenna í 10. bekk sem hafa prófað áfengi eða kannabis eftir tengslum við foreldra og sállíkamlegum einkennum (a.m.k. tveimur vikulega) - \%.

\begin{tabular}{lcccccc}
\hline & \multicolumn{2}{c}{ Slök tengsl } & \multicolumn{2}{c}{ Góð tengsl } & \multicolumn{2}{c}{ Mjög góð tengsl } \\
\hline$\geq 2$ sállíkamleg einkenni & Nei & Já & Nei & Já & Nei & Já \\
\hline Áfengi & & & & & & \\
\hline Aldrei & 57,6 & 52,3 & 77,0 & 62,4 & 82,1 & 73,2 \\
1-2 sinnum & 18,1 & 13,4 & 10,4 & 12,8 & 8,6 & 9,6 \\
3-5 sinnum & 10,0 & 10,5 & 6,7 & 8,5 & 4,5 & 6,8 \\
6-9 sinnum & 6,2 & 7,8 & 3,5 & 4,7 & 1,7 & 3,2 \\
10-19 sinnum & 3,3 & 7,8 & 0,7 & 5,4 & 1,6 & 2,4 \\
20-29 sinnum & 1,0 & 1,7 & 1,0 & 1,6 & 0,4 & 0,8 \\
$>30$ sinnum & 3,8 & 6,4 & 0,7 & 4,7 & 1,0 & 4,0 \\
\hline Kannabis & & & & & & \\
\hline Aldrei & 89,5 & 80,9 & 95,8 & 87,6 & 95,8 & 90,5 \\
1-2 sinnum & 1,4 & 6,1 & 1,7 & 3,9 & 1,9 & 3,6 \\
3-5 sinnum & 3,8 & 2,6 & 1,0 & 3,5 & 0,9 & 0,4 \\
6-9 sinnum & 0,5 & 2,0 & 0,0 & 1,9 & 0,3 & 0,0 \\
10-19 sinnum & 1,4 & 1,7 & 0,0 & 0,0 & 0,1 & 1,6 \\
20-29 sinnum & 0,0 & 2,3 & 0,2 & 0,0 & 0,0 & 1,2 \\
$>30$ sinnum & 3,3 & 4,3 & 1,2 & 3,1 & 1,0 & 2,8 \\
\hline
\end{tabular}


Línuleg aðhvarfsgreining var gerð til að spá fyrir um áfengisdrykkju út frá fjórum frumbreytum (tengslum við foreldra, sállíkamlegum einkennum a.m.k. tveimur vikulega, kyni og fjárhagsstöðu fjölskyldunnar). Eins og Tafla 5 sýnir pá spáðu tengsl við foreldra marktækt fyrir um áfengisdrykkju ungmenna en tengsl voru milli slakari tengsla við foreldra og áfengisneyslu ungmennanna. Vægi tengsla við foreldra minnkaði aðeins pegar líðan (a.m.k. tvær sállíkamlegar umkvartanir vikulega) var sett inn í líkanið en marktæk tengsl voru milli beggja breyta við áfengisneyslu. Pegar kynjabreytan var tekin inn í líkanið héldust fyrrnefnd tengsl en ekki reyndust marktæk tengsl kyns við áfengisneyslu. Pegar fjárhagsstaða fjölskyldunnar var tekin með í reikninginn kom í ljós að hún tengdist einnig marktækt líkum á áfengis- og kannabisneyslu ungmennanna. Fylgnistuðullinn $\mathrm{R}$ var ekki hár í pessum útreikningum, en hækkaði pegar sállíkamlegu umkvörtununum var bætt við líkanið, pó ekki með marktækum hætti. Sami útreikningur var gerður fyrir kannabisneyslu. Niðurstöðurnar voru ápekkar nema hvað fylgnin var minni, pó hún væri tölfræðilega marktæk á sama hátt og í áfengisdrykkjunni.

Tafla 5. Niðurstöður línulegrar aðhvarfsgreiningar á áfengisdrykkju og kannabisneyslu út frá tengslum við foreldra, líðan (sállíkamlegum umkvörtunum a.m.k. tveimur vikulega), kyni og fjárhagsstöðu fjölskyldu.

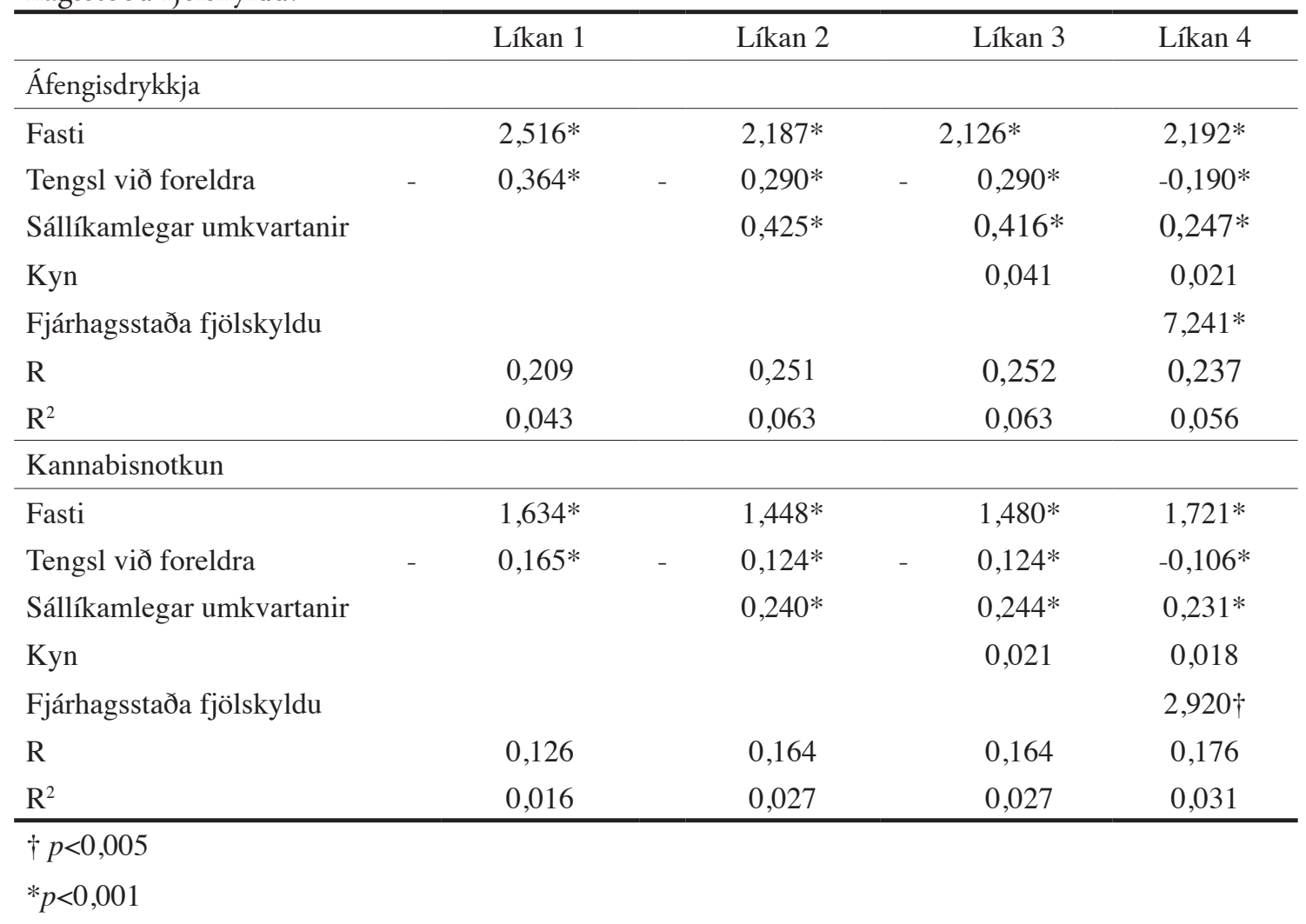

\section{Umræða}

Vitað er að fjölmargir einstaklings- og umhverfispættir skipta máli fyrir velferð ungmenna og möguleika peirra á farsæld til framtíðar (Bronfenbrenner, 2005; Lansford og Banati, 2018). İ rannsókn pessari var sjónum einkum beint að líðan og vímuefnaneyslu ungmenna og pessir pættir skoðaðir í tengslum við gæði tengsla við foreldra. Pá var líðan ungmenna og tengsl við foreldra skoðuð í tengslum við vímuefnaneyslu ungmenna. Meginniðurstöður rannsóknarinnar eru fimm.

Í fyrsta lagi komu fram tengsl milli pess að ungmenni væru í slökum tengslum við foreldra og pess að pau væru líklegri en pau sem eru í betri tengslum, til að líða verr og upplifa fleiri sállíkamleg einkenni. Pessi niðurstaða styður tilgátu 1. Á svipuðum nótum kom fram í rannsókn Manning og Gregoire (2009) að ungmenni sem alast upp við tengslavanda vegna vímuefnaneyslu foreldra séu líklegri 
til að próa með sér geðraskanir. Pá hafa Moore og félagar (2018) bent á að góð samskipti á heimilinu styðji við betri geðheilsu. Jafnframt hefur íslensk rannsókn bent á að ungmennum, sem upplifa samheldni í fjölskyldunni í ríkari mæli en önnur ungmenni, líður betur (Sigrún Aðalbjarnardóttur, 2019) og pau sýna færri depurðar- og punglyndiseinkenni (Sigrún Aðalbjarnardóttir og Kristín Lilja Garðarsdóttir, 2004).

Í öðru lagi mátti í niðurstöðum sjá að ungmenni sem eru í slökum tengslum við foreldra sína eru tvöfalt líklegri til að hafa reynslu bæði af áfengis- og kannabisneyslu og pað í meiri mæli en peir sem eru í góðum tengslum við foreldra. Ungmenni sem voru í slökum tengslum við foreldra sína voru prefalt líklegri en pau sem voru í mjög góðum tengslum til pess að hafa reynslu af notkun vímugjafanna. Pessi niðurstaða styður tilgátu 2. Bornstein og Putnick (2018) hafa einmitt bent á mikilvægi öruggra tengsla foreldris og barns par sem rætt er saman um mikilvæg mál og foreldrið styður ungmennið við að taka góðar ákvarðanir. Donovan (2018) hefur á sömu nótum bent á mikilvægi tengsla ungmenna og foreldra og samræðna sem snúa beint að notkun vímugjafa. Hér á landi hafa rannsóknir sýnt að pegar foreldrar byggja upp góð tengsl við barn sitt með pví að sýna pví áhuga, hvetja pað og sýna stuðning pá dragi pað úr líkum á að ungmenni neyti áfengis og drekki illa og noti kannabis (Sigrún Aðalbjarnardóttir og Leifur Geir Hafsteinsson, 2001).

Í priðja lagi komu fram tengsl milli pess að ungmenni upplifi vanlíðan í formi sállíkamlegra einkenna, hafi slök tengsl við foreldra og búi við verri fjárhagsstöðu fjölskyldu og pess að vera líklegri en pau sem líður betur og hafa betri tengsl við foreldra til að hafa notað vímuefni, bæði áfengi og kannabis. Í pessari rannsókn var jafnframt skoðað hvort tengsl væru milli vanlíðunar og vímuefnaneyslu óháð tengslum ungmenna við foreldra sína og reyndist svo vera. Tilgáta 3 er pví staðfest. Á svipuðum nótum hefur komið fram að ungmenni sem sýna meiri depurðar- og punglyndiseinkenni eru líklegri til að neyta áfengis og annarra vímuefna (Sigrún Aðalbjarnardóttir, 2019, bls. 274-275).

Í fjórða lagi kom fram að ekki var samband milli kyns og áfengis- eða kannabisneyslu ungmennanna. Í niðurstöðum má sjá að stúlkur nota ekki minna áfengi en drengir pó kannabisneysla peirra sé minni. Einnig voru stúlkurnar líklegri en drengir til að meta tengsl við foreldra sína slök og ólíklegri til að meta tengslin sem mjög góð. Tilgátu 4 var pví hafnað.

Í fimmta lagi reyndust tengsl milli fjárhagsstöðu fjölskyldu og áfengis- og kannabisneyslu ungmennanna. Pví verri sem fjárhagsstaðan var pví líklegri voru ungmennin til að hafa reynslu af áfengis- og kannabisneyslu. Tilgáta 5 er pví staðfest. Pað parf ekki að koma á óvart í ljósi niðurstaðna í rannsókn Ársæls Arnarssonar og félaga (2020) sem sýndu að börn sem upplifa fjárhagsstöðu fjölskyldunnar slæma eiga í verri samskiptum við foreldra sína en pau sem meta fjárhagsstöðuna góða. Aðeins 7\% barna sem mátu fjárhagsstöðu fjölskyldunnar mjög góða sögðust eiga erfið samskipti við foreldra sína, á móti tæpum 70\% peirra sem mátu fjárhag fjölskyldunnar mjög slæman.

Mikilvæg niðurstaða rannsóknarinnar er að pau ungmenni sem eru í slæmum tengslum við foreldra eða búa við andlega vanlíðan séu í aukinni hættu á að nota áfengi og kannabis á unglingsaldri og pað í meira mæli.

Rannsóknir sem skoðað hafa tíðni geðraskana (Collishaw, 2015; Mojtabai o.fl., 2016) og sállíkamlegra einkenna (Aanesen o.fl., 2017) hjá ungmennum á Vesturlöndum, hafa sýnt að frá aldamótum hefur andleg vanlíðan barna og ungmenna aukist. Hér á landi hafa rannsóknir sýnt aukningu einkenna eins og depurðar (Ársæll Arnarsson, 2019) og í tölum frá Embætti landlæknis (2021a) kemur fram að á árunum 2019 og 2020 var ungt fólk á aldrinum 18-24 ára ólíklegast af aldurshópum fullorðinna til að meta andlega heilsu sína góða eða mjög góða (59\% karlar; 53\% konur). Geðraskanir eru jafnframt fjölmennasti flokkur greininga til grundvallar 75\% örorku- og endurhæfingarmats hér á landi og á tímabilinu 2008-2018 var fjölgun greininga á Íslandi mest í flokknum „geðraskanir og aðrar ástæður“" (Kolbeinn H. Stefánsson, 2019).

Af pessu má sjá að aðkallandi er að hlúa betur að andlegri líðan ungmenna. Vitað er að snemmbær inngrip geta skipt sköpum við að draga úr einkennum og fyrirbygga frekari vanda síðar (Holstein 
o.fl., 2015; Kessler o.fl., 2003). Niðurstöður rannsóknarinnar gefa til kynna að foreldrar gegni par mikilvægu hlutverki með pví að hlúa að góðum tengslum við börn sín sem jafnframt eykur líkur á að foreldrar taki eftir merkjum um andlega vanlíðan peirra. Mikilvægt er einnig að auka færni foreldra til pess að pekkja og bregðast við merkjum um andlega vanlíðan hjá börnum sínum en niðurstöður rannsókna hafa einmitt bent á að ekki eigi síður að horfa eftir ósértækum birtingarmyndum vanlíðunar (Ravens-Sieberer o.fl., 2009) eins og skoðaðar voru í pessari rannsókn. Foreldrar purfa jafnframt að taka mark á upplifun barna sinna af líðan en rannsóknir benda til pess að eigið mat ungmenna spái betur fyrir um geðheilsu peirra en upplifun foreldranna (Patalay o.fl., 2015).

Athyglisverð er einnig sú niðurstaða rannsóknarinnar að vanlíðan sem kemur fram í sállíkamlegum einkennum er áhættupáttur fyrir áfengis- og kannabisneyslu ungmennanna óháð tengslum við foreldra. Petta er enn frekari brýning á að íslenskt samfélag tryggi fræðslu til uppeldisaðila og hæfni fagfólks sem starfar með börnum til að bregðast við andlegri vanlíðan. Einnig parf að tryggja fjölbreytt stuðningsúrræði í skólum og síðast en ekki síst að bæta aðgengi að geðheilbrigðispjónustu og skort á samfellu pjónustunnar við ungmenni fyrir og eftir 18 ár aldur, einkum við börn og ungmenni með tvígreiningu á geð- og fíknivanda (Embætti landlæknis, 2018). WHO (2017) hefur einmitt vegna vaxandi geðheilbrigðisvanda ungmenna hvatt aðildarríki sín til að leggja áherslu á sambærilega pætti; fræðslu, forvarnir, inngrip velferðarkerfa og pað að auka hæfni uppeldisaðila til að takast á við andlega vanlíðan barna og ungmenna.

Niðurstöður rannsóknarinnar benda einnig til tengsla á milli pess að ungmenni búi við verri efnahagsleg kjör og að pau noti vímuefni á unglingsaldri. Í nágrannalöndum hafa komið fram svipaðar vísbendingar (Manhica o.fl., 2021). Brýnt er pví að félagsleg kerfi samfélagsins búi öllum börnum viðunandi aðstæður og að pau og fjölskyldur peirra fái pann stuðning sem pau purfa á að halda.

Rétt er að geta pess að peir pættir sem skoðaðir voru í rannsókninni (andleg vanlíðan og tengsl við foreldra) í tengslum við áfengis- og kannabisneyslu, hafa einir og sér ekki hátt skýringargildi. Til dæmis má sjá að pað eru ekki einungis ungmenni með slök tengsl sem drekka eða nota kannabis en við túlkun pessara niðurstaðna parf að hafa tvennt í huga. Í fyrsta lagi voru pátttakendur nemendur í 10. bekk grunnskóla. Með sameiginlegu átaki peirra sem standa að börnum og ungmennum hér á landi tókst á fyrsta tug nýrrar aldar að draga verulega úr unglingadrykkju frá pví sem áður tíðkaðist (Álfgeir L. Kristjánsson o.fl., 2016). Staðan er pví sú að mun minni hópur ungmenna í grunnskóla notar vímuefni nú en áður og af pessum sökum kemur pað ekki á óvart að spápátturinn sé ekki hár. Horfa parf pó til pess að neysla vímuefna tvöfaldast pegar ungmenni koma á framhaldsskólaaldur (Margrét Lilja Guðmundsdóttir o.fl., 2020) og vímuefnaneysla peirra sem ekki halda áfram námi, eru aðallega í vinnu eða atvinnulaus, er tvöfalt meiri en peirra sem halda áfram námi (Hrefna Pálsdóttir o.fl., 2010). Eftir 18 ára aldur eykst áfengisneysla síðan enn meira og er hlutfall fullorðinna sem stunda áhættudrykkju hæst á aldrinum 18-34 ára (Embætti landlæknis, 2021b). Í öðru lagi parf að hafa í huga að við 15 ára aldur hefur einungis helmingur geðraskana komið fram og prír fjórðu við 24 ára aldur (Kessler o.fl., 2005). Pví má ætla að strax pegar unga fólkið er orðið eldra myndi vanlíðan tengjast vímuefnaneyslu unga fólksins með enn skýrari hætti og hafa erlendar rannsóknir gefið slíkt til kynna (Rose o.fl., 2001). Pá parf að horfa til pess að á sỉðari hluta pess tímabils sem einstaklingar eru skilgreindir ungt fólk (12-24 ára) dregur smám saman úr verndandi páttum uppeldisáranna, eins og eftirliti og stuðningi foreldra og velferðarpjónustu sem býðst meðan ungmennið er „barn“ pað er fram til 18 ára aldurs. Við 18 ára aldur skapast oft gap í pjónustu við ungmenni sem snýr að andlegum veikindum og vímuefnaneyslu (Embætti landlæknis, 2018). Slík staða dregur úr velferð pessa hóps og líkum á virkri pátttöku í samfélaginu (Office of the Minister for Social Development, 2016).

\section{Lokaorð}

Í rannsókn pessari voru hjá ungmennum skoðuð merki um andlega vanlíðan, tengsl við foreldra og áfengis- og kannabisneyslu. Nýnæmi rannsóknarinnar felst í að beina sjónum að margs konar tengslum pessara pátta. Í ljósi pess að ungmenni bæði hér á landi og erlendis glíma við vaxandi vanlíðan og streitu (Baxter o.fl., 2014; Gunnhildur Arna Gunnarsdóttir, 2021), er aðkallandi að 
skoða hvernig hægt er að draga úr eða koma í veg fyrir að slík líðan próist á verri veg (Graber o.fl., 2014; Sawyer o.fl., 2018) og ungmenni leiti til bjargráða eins og vímuefna til pess að deyfa vanlíðan.

Pví ber að fagna að tekist hafi að draga úr vímuefnaneyslu grunnskólanema. Ekki er pó nóg að rýna í tölfræði sem snýr að heildarhóp ungmenna eingöngu. Samhliða parf að skoða pann hóp sem glímir við margvíslegar áskoranir; sem býr við erfiðar uppeldisaðstæður, líður illa og eru í mestri hættu á að próa með sér vímuefnavanda og alvarlegar geðraskanir. Auka parf stuðning við pennan hóp í samfélagi okkar. Í pessu sambandi vitnum við að lokum í orð ungs manns (18 ára) og ungrar konu (24 ára) úr viðtölum sem eru hluti rannsóknargagnasafns sem höfundar vinna nú úr. Einstaklingarnir glíma báðir við langvarandi alvarlegan vímuefnavanda og hafa reynslu af vanlíðan og erfiðum uppeldisaðstæðum par sem peir upplifðu ekki öryggi eða að geta leitað hjálpar hjá fullorðnum aðila í aðstæðum sínum. Í frásögn peirra er vitnað til geðraskana heimilisfólks (Manning og Gregoire, 2009; Meyers og Dick, 2010), vanrækslu og slæmra tengsla við foreldra og pýðingu pessa fyrir líðan peirra og áhættuhegðun (Otten o.fl., 2019; Sigrún Aðalbjarnardóttir, 2019).

Síðan ég man eftir mér ... [er ég] búinn að vera mjög punglyndur og kvíðinn ... ég á bróður sem er mjög veikur á geði ... pabbi er rosalega punglyndur og tekur pað svolítið út á okkur á heimilinu ... maður var alltaf tiplandi á tánum ... Ég var bara kominn með leið á hvernig heimurinn var og hvernig ástandið á mér væri ... mér leið alltaf illa og síðan pegar ég var búinn að fá mér [vímuefni] pá bara svona var ég ekkert að pæla í neinu ... [en] pessi raunveruleiki [að líða betur í vímu] ... er bara löngu farinn ... mér líður illa pegar ég er í pví ... mig langar að vera edrú ... meira en allt ... pað bara gerist aldrei ... ég hef aldrei náð neinum edrútíma.

Ég ól mig sjálf upp ... ég veit ekki hvernig ég á að orða petta en mamma mín sem sagt lamdi mig pegar ég var yngri og kenndi mér um allt heima ... ég purfti að taka til og sjá um heimilið frá pví að ég man eftir mér ... ég var lögð í einelti af skólafélögum og ... enginn pældi í neinu ... ég byrjaði að reykja kannabis pegar ég var 10 ára ... byrjaði að reykja daglega 11 ára ... fann mér leið til pess að deyfa sársaukann ... ég vildi bara deyfa mig ... flýja ... loka á tilfinningarnar og hugsanirnar.

\section{Young people's drug consumption viewed in the light of their mental well-being and relationship with parents}

During adolescence, individuals face various changes and challenges. Parents tend to become insecure in the parenting role during these years. Concerns have been directed at how their children will fare in the coming years and in the future. Some caregivers strive to prepare them as best they can, fostering their well-being, communication skills, and health. Others experience challenges in their upbringing, feeling that they are losing control and unable to steer the child in the right direction. This is not without reason. The period of adolescence increases young people's vulnerability to mental health problems as many mental illnesses appear during these years. Mental well-being is the prerequisite for people's prosperity both as individuals as well as citizens where everyone's ingenuity and skills should be recognized. It is, therefore, worrying that mental stability is deteriorating among young people in the Western world. Mental health policy has been called on as well as different resources and treatments and already many nations have placed mental health at the center of their agendas. In adolescence experiments with substances are also common. In Iceland adolescent binge drinking was strikingly common in the 70s, 80s and 90s but with joint preventive efforts of parents, schools, and authorities there has been a positive trend in the direction of much less alcohol being used by teenagers in junior high school. However, as teenagers get older, substance use rises, both in frequency as well as quantity, with increasing variety of substance types. Since the 80 s there has also been constant growth in adult alcohol consumption in Iceland and young people aged 
18-34, are among these consumers and the group at greatest risk for heavy drinking. Cannabis use among adolescents in Iceland is also on the rise, even in junior high school. In addition, young people are using more prescription drugs. All this is a matter of concern. Studies in Iceland have focused on different risk and protective factors, both related to mental well-being and substance use. Various aspects have been examined, relating both to individuals and the environment. The aim of this study is: Firstly, to map young people's drug consumption and mental well-being by using a measure of psychosomatic symptoms. Secondly, to examine these factors in relation to gender and the quality of the young people's relationship with parents. Thirdly, to explore young people's mental well-being, the quality of their relationship with parents, their gender and economic background in relation to their alcohol and cannabis use. The data used came from the study, Health Behaviors in School-Aged Children. Students in 10th grade answered a questionnaire asking about these factors. The results showed that a quarter of young people experience poor relationships with their parents and that they are more likely to feel bad and use alcohol and cannabis than those who experience good or very good relationships. Girls did not use less alcohol than boys, although their cannabis use was lower, and they were more likely than boys to evaluate their relationship with their parents as poor and less likely to evaluate it as good. There was a connection between the young people's dysphoria that appeared as psychosomatic symptoms, a poor relationship with parents and a poor economic background and being more likely to have an experience of using both alcohol and cannabis than those who feel better, have a better relationship and a higher economic background. There was also an association between dysphoria and alcohol and cannabis use, regardless of the young people's relationship with their parents. The findings emphasize the importance of early intervention when symptoms of dysphoria appear. Parents need to be encouraged to nurture good relationships with their children, discuss daily issues and challenges with them to help them take better decisions. Caregivers' aptitude to recognize early signs of young people's dysphoria needs to be improved as well as their ability to respond to it and provide them with further services. Finally, it is essential to ensure better access to mental health services, to reduce the likelihood of their condition deteriorating further as well as drug abuse becoming their lifeline to feel better.

Key words: Adolescents, parents, dysphoria, psychosomatic symptoms, substance abuse, HBSC

\section{Um höfunda}

Ragný Póra Guðjohnsen (ragny@hi.is) er lektor í uppeldis- og menntunarfræði við Menntavísindasvið Háskóla Íslands. Hún lauk embættisprófi í lögfræði 1992, MS-gráðu í uppeldis- og menntunarfræði 2009 og doktorsprófi í sömu grein árið 2016 frá Háskóla Íslands. Rannsóknir hennar snúa annars vegar að áhættuhegðun og velferð ungs fólks og hins vegar að borgaravitund og borgaralegri pátttöku ungmenna.

Ársæll Arnarsson (arsaell@hi.is) er prófessor í tómstunda- og félagsmálafræði við Menntavísindasvið Háskóla Íslands. Hann lauk BA-prófi í sálfræði 1993, MS-gráðu í heilbrigðisvísindum 1997 og PhD-gráðu í líf- og læknavísindum árið 2009 frá Háskóla Íslands. Síðastliðinn áratug hafa rannsóknir hans aðallega beinst að heilsufari og líðan unglinga. 


\section{About the authors}

Ragný Póra Guðjohnsen (ragny@hi.is) is an assistant professor in education studies in the University of Iceland, School of Education. She completed a Ph.D. degree in education in 2016, an MA degree in education studies in 2009 and a Cand. Jur. degree in law in 1992, all at the University of Iceland. Her research focuses on young people's well-being and risk behavior as well as on their civic awareness and engagement.

Ársæll Arnarsson (arsaell@hi.is) is a professor of leisure studies in the University of Iceland School of Education. He completed a BA degree in psychology in 1993, an MSc degree in health sciences in 1997 and a $\mathrm{PhD}$ in biomedical sciences in 2009, all from the University of Iceland. For the past decade his research has focused on the health and well-being of adolescents.

\section{Heimildir}

Aanesen, F., Meland, E. og Torp, S. (2017). Gender differences in subjective health complaints in adolescence: The roles of self-esteem, stress from schoolwork and body dissatisfaction. Scandinavian Journal of Public Health, 45(4), 389-396. https://doi.org/10.1177/1403494817690940

Ainsworth, M. D. (1973). The development of infant mother attachment. İ B. M. Caldwell og H. N. Ricciuti (ritstjóri), Review of child development research (3. bindi) (bls. 1-94). University of Chicago Press.

Andersen, P. L. og Dæhlen, M. (2017). Sosiale relasjoner i ungdomstida - Identifisering og beskrivelse av ungdom med svake relasjoner til foreldre, skole og venner. Norsk institutt for forskning om oppvekst, velferd og aldring. http://hdl.handle.net/20.500.12199/5114

Arnarsson, A. M., Kristofersson, G. K. og Bjarnason, T. (2018). Adolescent alcohol and cannabis use in Iceland 1995-2015. Drug and Alcohol Review, 37(1), S49-S57. https://doi.org/10.1111/dar.12587

Álfgeir L. Kristjánsson, Inga Dóra Sigfúsdóttir, Pórólfur Pórlindsson, Mann, M. J., Jón Sigfússon og Allegrante, J. P. (2016). Population trends in smoking, alcohol use and primary prevention variables among adolescents in Iceland, 1997-2014. Addiction, 111(4), 645-652. https://doi.org/10.1111/add.13248

Ársæll Arnarsson. (2019). Depurð meðal skólabarna á Íslandi. Sérrit Netlu 2019-Alpjóðlegar menntakannanir. https://doi.org/10.24270/serritnetla.2019.30

Ársæll Arnarsson, Sigrún Danílsdóttir og Rafn Jónsson. (2020). Félagstengsl islenskra barna og ungmenna. https:// www.landlaeknir.is/servlet/file/store93/item41614/Félagstengsl barna og ungmenna_LOK.pdf

Baumrind, D. (1971). Current patterns of parental authority. Developmental Psychology Monographs, 4(1), 1-103. https://doi.org/10.1037/h0030372

Baumrind, D. (1991). The influence of parental style on adolescent competence and substance use. Journal of Early Adolescence, 11(1), 56-95. https://doi.org/10.1177/0272431691111004

Baxter, A. J., Scott, K. M., Ferrari, A. J., Norman, R. E., Vos, T. og Whiteford, H. A. (2014). Challenging the myth of an "epidemic" of common mental disorders: Trends in the global prevalence of anxiety and depression between 1990 and 2010. Depression and Anxiety, 31(6), 506-516. https://doi.org/10.1002/da.22230

Bornstein, M. H. og Putnick, D. L. (2018). Parent-adolescent relationships in global perspective. Í J. E. Lansford og P. Banati (ritstjórar), Handbook of adolescent development research and its impact on global policy (bls. 107-129). Oxford Scholarship.

Bountress, K. og Chassin, L. (2015). Risk for behavior problems in children of parents with substance use disorders. The American Journal of Orthopsychiatry, 85(3), 275-286. https://doi.org/10.1037/ort0000063

Bowlby, J. (1988). A secure base: Clinical applications of attachment theory. Routledge.

Bronfenbrenner, U. (2005). Interacting systems in human development. Research paradigms: Present and future (1988). Í U. Bronfenbrenner (ritstjóri), Making human beings human: Bioecological perspectives on human development (bls. 67-93). Sage. 
Collishaw, S. (2015). Annual research review: Secular trends in child and adolescent mental health. Journal of Child Psychology and Psychiatry, 56(3), 370-393. https://doi.org/10.1111/jcpp.12372

Conners-Burrow, N. A., McKelvey, L. M., Pemberton, J. R., Mesman, G. R., Holmes, K. J. og Bradley, R. H. (2015). Buffering the negative effects of maternal alcohol problems on child behavior. Journal of Family Psychology, 29(4), 576-584. https://doi.org/10.1037/fam0000121

Conway, K. P., Swendsen, J., Husky, M. M., He, J. P. og Merikangas, K. R. (2016). Association of lifetime mental disorders and subsequent alcohol and illicit drug use: Results from the national comorbidity survey-adolescent supplement. Journal of the American Academy of Child and Adolescent Psychiatry, 55(4), 280-288. https:// doi.org/10.1016/j.jaac.2016.01.006

Crone, E. A. og Fuligni, A. J. (2020). Self and others in adolescence. Annual Review of Psychology, 71, 447-469. https://doi.org/10.1146/annurev-psych-010419-050937

Deighton, J., Lereya, S. T., Casey, P., Patalay, P., Humphrey, N. og Wolpert, M. (2019). Prevalence of mental health problems in schools: Poverty and other risk factors among 28,000 adolescents in England. The British Journal of Psychiatry, 215(3), 565-567. https://doi.org/10.1192/bjp.2019.19

DeLuca, J. S. (2020). Conceptualizing adolescent mental illness stigma: Youth stigma development and stigma reduction programs. Adolescent Research Review, 5, 153-171. https://doi.org/10.1007/s40894-018-0106-3

Donovan, J. E. (2018). A framework for studying parental socialization of child and adolescent substance use. Í H. E. Fitzgerald og L. I. Puttler (ritstjórar), Alcohol use disorders: A developmental science approach to etiology (bls. 143-180). Oxford University Press.

Embætti landlæknis. (2018). Stöðugreining og framtiððarsýn i geðheilbrigðismálum barna og ungmenna á Islandi. https:/www.landlaeknir.is/servlet/file/store93/item34860/Stodugreining $\% 20$ og\%20framtidarsyn $\% 20 \mathrm{i} \% 20$ gedheilbrmalum\%20barna\%20og\%20ungmenna\%20a\%20Islandi_April\%202018.pdf

Embætti landlæknis. (2021a). Talnabrunnur. Liðan fullorðinna Íslendinga árið 2020. https://www.landlaeknir. is/servlet/file/store93/item44506/Talnabrunnur_Mars_2021.pdf

Embætti landlæknis. (2021b). Talnabrunnur. Vöktun áhrifapátta. Áfengis-og tóbaksnotkun 2020. https://www. landlaeknir.is/servlet/file/store93/item44366/Talnabrunnur_Februar_2021.pdf

Gariepy, G., McKinnon, B., Sentenac, M. og Elgar, F. J. (2016). Validity and reliability of a brief symptom checklist to measure psychological health in school-aged children. Child Indicators Research, 9, 471-484. https://doi.org/10.1007/s12187-015-9326-2

Gili, M., Castellví, P., Vives, M., de la Torre-Luque, A., Almenara, J., Blasco, M. J., Cebrià, A. I., Gabilondo, A., Pérez-Ara, M. Á., Miranda-Mendizábal, A., Lagares, C., Parés-Badell, O., Piqueras, J. A., Rodríguez-Jiménez, T., Rodríguez-Marín, J., Soto-Sanz, V., Alonso, J. og Roca, M. (2019). Mental disorders as risk factors for suicidal behavior in young people: A meta-analysis and systematic review of longitudinal studies. Journal of Affective Disorders, 245, 152-162. https://doi.org/10.1016/j.jad.2018.10.115

Gísli Kort Kristófersson, Ársæll Arnarsson, Guðmundur Torfi Heimisson og Dagbjört Sigurðardóttir. (2017). Ólögmæt dreifing örvandi lyfseðilsskyldra lyfja meðal unglinga í 10. bekk. Laknablaðið, 103(12), 537-541. https://doi.org/10.17992/lbl.2017.12.164

Graber, J. A., Hill, J. C. og Saczawa, M. E. (2014). Childhood and the entry into adolescence: A pivotal period in health-related behaviors and prevention. İ Z. Sloboda og H. Petras (ritstjórar), Defining prevention science (bls. 59-86). Springer. https://doi.org/10.1007/978-1-4899-7424-2_3

Guðrún Ágústa Ágústsdóttir. (2021, 28. janúar). Ungmenni fá nikótín, koffín og kannabis í morgunmat. Visir. https://www.visir.is/g/20212066629d

Gunnhildur Arna Gunnarsdóttir. (2021). Fleiri börn í bráđainnlögn á BUGL vegna sjálfsvígshugsana - rætt við Bertrand Andre Marc Lauth, geðlækni. Laknablaðið, 107(5), 250-251.

Haugland, S. og Wold, B. (2001). Subjective health complaints in adolescence: Reliability and validity of survey methods. Journal of Adolescence, 24(5), 611-624. https://doi.org/10.1006/jado.2000.0393

Holstein, B. E., Andersen, A., Fotiou, A., Gobina, I., Godeau, E., Hansen E. H., Iannotti, R., Levin, K., Gabhainn, S. N., Ravens-Sieberer, U. og Välimaa, R. (2015). Adolescents' medicine use for headache: Secular trends in 20 countries from 1986 to 2010. European Journal of Public Health, 25(2), 76-79. https:// doi.org/10.1093/eurpub/ckv035 
Hrefna Pálsdóttir, Álfgeir Logi Kristjánsson, Inga Dóra Sigfúsdóttir, Birna Baldursdóttir og Jón Sigfússon. (2010). Ungt fólk utan skóla 2009. Félagsleg staða 16-20 ára ungmenna á Íslandi sem ekki stunda nám við framhaldsskóla árið 2009. https://www.stjornarradid.is/gogn/rit-og-skyrslur/stakt-rit/2010/02/09/Ungt-folk-utan-skola2009-felagsleg-stada-16-20-ara-ungmenna-a-Islandi-sem-ekki-stunda-nam-vid-framhaldsskola-arid-2009/

Hutchings, M. og Kazmi, N. (2015). Exam factories? The impact of accountability measures on children and young people. National Union of Teachers.

Inchley, J., Currie, D., Budisavljevic, S., Torsheim, T., Jåstad, A., Cosma, A., Kelly, C., Arnarsson, Á. M., Barnekow, V. og Weber, M. M. (ritstiórar). (2020). Spotlight on adolescent health and well-being. Findings from the 2017/2018 Health behaviour in school-aged children (HBSC) survey in Europe and Canada. International report. https://www.euro.who.int/en/health-topics/Life-stages/child-and-adolescent-health/health-behaviourin-school-aged-children-hbsc/publications/2020/spotlight-on-adolescent-health-and-well-being.-findingsfrom-the-20172018-health-behaviour-in-school-aged-children-hbsc-survey-in-europe-and-canada.-international-report.-volume-2.-key-data

Ingibjörg Eva Pórisdóttir, Bryndís Björk Ásgeirsdóttir, Álfgeir Logi Kristjánsson, Heiðdís Björk Valdimarsdóttir, Erla María Jónsdóttir Tölgyes, Jón Sigfússon, Allegrante, J. P., Inga Dóra Sigfúsdóttir og Pórhildur Halldórsdóttir (2021). Depressive symptoms, mental wellbeing and substance use among adolescents before and during the COVID-19 pandemic in Iceland: A longitudinal, population-based study. The Lancet Psychiatry, 8(8), 663-672. https://doi.org/10.1016/S2215-0366(21)00156-5

Kessler, R. C., Berglund, P., Demler, O., Jin, R., Merikangas, K. R. og Walters, E. E. (2005). Lifetime prevalence and age-of-onset distributions of DSM-IV disorders in the National comorbidity survey replication. Archives of General Psychiatry, 62(6), 593-602. https://doi.org/10.1001/archpsyc.62.6.593

Kessler, R. C., Merikangas, K. R., Berglund, P., Eaton, W. W., Koretz, D. S. og Walters E. E. (2003). Mild disorders should not be eliminated from the DSM-V. Archives of General Psychiatry, 60(11), 1117-1122. https://doi.org/10.1001/archpsyc.60.11.1117

Kolbeinn H. Stefánsson. (2019). Fjöldapróun örorkulifeyrispega. https://www.obi.is/static/files/skjol/pdfskjol/2019-09-sky-rsla-fjo-ldathro-un-o-bi-khs-utg-1.pdf

Koning, I. M., van den Eijnden, R. J., Verdurmen, J. E., Engels, R. C. og Vollebergh, W. A. (2012). Developmental alcohol-specific parenting profiles in adolescence and their relationships with adolescents' alcohol use. Journal of Youth Adolescence, 41(11), 1502-1511. https://doi.org/10.1007/s10964-012-9772-9

Landspítali. (2021, mars). Starfsemisupplýsingar Landspitala. https:/www.landspitali.is/library/Sameiginlegar-skrar/Gagnasafn/Rit-og-skyrslur/Starfsemisupplysingar-LSH/2021/Starfsemisupplysingar_LSH_mars_2021_2. pdf

Lansford, J. E. og Banati, P. (2018). Handbook of adolescent development research and its impact on global policy. Oxford Scholarship.

Låftman, S. B., Bergström, M., Modin, B. og Östberg, V. (2014). Joint physical custody, turning to parents for emotional support, and subjective health: A study of adolescents in Stockholm, Sweden. Scandinavian Journal of Public Health, 42(5), 456-462. https://doi.org/10.1177/1403494814526798

Maccoby, E. E. og Martin, J. A. (1983). Socialization in the context of the family: Parent-child interaction. Í P. H. Mussen (ritstjóri), Handbook of child psychology: Volume 4, Socialization, personality, and social development (bls. 1-101). Wiley.

Manhica, H., Straatmann, V. S., Lundin, A., Agardh, E. og Danielsson, A. K. (2021). Association between poverty exposure during childhood and adolescence, and drug use disorders and drug-related crimes later in life. Addiction, 116(7), 1747-1756. https://doi.org/10.1111/add.15336

Manning, C. og Gregoire, A. (2009). Effects of parental mental illness on children. Psychiatry, 8(1), 7-9. https:// doi.org/10.1016/j.mppsy.2008.10.012

Margrét Lilja Guðmundsdóttir, Jón Sigfússon, Erla María Tölgyes, Ingibjörg Eva Pórisdóttir, Porfinnur Skúlason, Inga Dóra Sigfúsdóttir og Álfgeir Logi Kristjánsson. (2020). Ungt fólk 2020. Framhaldsskólanemar. https:// rannsoknir.is/wp-content/uploads/2021/01/Ungt-folk-_-Framhaldsskolar-2020.pdf

Meyers, J. L. og Dick, D. M. (2010). Genetic and environmental risk factors for adolescent-onset substance use disorders. Child and Adolescent Psychiatric Clinics of North America, 19(3), 465-477. https://doi.org/10.1016/j. chc.2010.03.013 
Milburn, D. M., Fass, D. og Arseneault, L. (2017). The Prince's trust macquarie youth index 2017. https://www. princes-trust.org.uk/about-the-trust/research-policies-reports/research

Mojtabai, R., Olfson, M. og Han, B. (2016). National trends in the prevalence and treatment of depression in adolescents and young adults. Pediatrics, 138(6), e20161878. https://doi.org/10.1542/peds.2016-1878

Mojtabai, R., Stuart, E. A., Hwang, I., Eaton, W. W., Sampson, N. og Kessler, R. C. (2017). Long-term effects of mental disorders on marital outcomes in the National comorbidity survey ten-year follow-up. Social Psychiatry and Psychiatric Epidemiology, 52(10), 1217-1226. https://doi.org/10.1007/s00127-017-1373-1

Moore, G. F., Cox, R., Evans, R. E., Hallingberg, B., Hawkins, J., Littlecott, H. J., Long, S. J. og Murphy, S. (2018). School, peer and family relationships and adolescent substance use, subjective wellbeing and mental health symptoms in Wales: A cross sectional study. Child Indicators Research, 11(6), 1951-1965. https:// doi.org/10.1007/s12187-017-9524-1

Odgers, C. L. og Jensen, M. R. (2020). Annual research review: Adolescent mental health in the digital age: Facts, fears and future directions. The Journal of Child Psychology and Psychiatry, 61(3), 336-348. https:// doi.org/10.1111/jcpp.13219

Office of the Minister for Social Development [New Zealand]. (2016). Investing in children legislative reform: paper seven - Transition to independence - Discretion to support young people up to age 25. https://www.msd. govt.nz/documents/about-msd-and-our-work/work-programmes/investing-in-children/cabinet-paper-transition-up-to-25.pdf

Otten, R., Mun, C. J., Shaw, D. S., Wilson, M. N. og Dishion, T. J. (2019). A developmental cascade model for early adolescent-onset substance use: The role of early childhood stress. Addiction, 114(2), 326-334. https:// doi.org/10.1111/add.14452

Ottová-Jordan, V., Smith, O. R. F., Augustine, L., Gobina, I., Rathmann, K., Torsheim, T., Mazur, J., Välimaa, R., Cavallo, F., Klanscek, H. J., Vollebergh, W., Meilstrup, C., Richter, M., Moor, I. og Ravens-Sieberer, U. (2015). Trends in health complaints from 2002 to 2010 in 34 countries and their association with health behaviours and social context factors at individual and macro-level. European Journal of Public Health, 25(2), 83-89. https://doi.org/10.1093/eurpub/ckv033

Patalay, P., Fonagy, P., Deighton, J., Belsky, J., Vostanis, P. og Wolpert, M. (2015). A general psychopathology factor in early adolescence. British Journal of Psychiatry, 207(1), 15-22. http://discovery.ucl.ac.uk/1455635

Pitchforth, J., Fahy, K., Ford, T., Wolper, M., Viner, R. M. og Hargreaves, D. S. (2019). Mental health and well-being trends among children and young people in the UK, 1995-2014: Analysis of repeated cross-sectional national health surveys. Psychological Medicine, 49(8), 1275-1285. https://doi.org/10.1017/ S0033291718001757

Polanczyk, G. V., Salum, G. A., Sugaya, L. S., Caye, A. og Rohde, L. A. (2015). Annual research review: A meta-analysis of the worldwide prevalence of mental disorders in children and adolescents. Journal of Child Psychology and Psychiatry, and Allied Disciplines, 56(3), 345-365. https://doi.org/10.1111/jcpp.12381

Ramberg, J., Lénárt, A. og Watkins, A. (2020). European agency statistics on inclusive education: 2018 dataset cross-country report. https://www.european-agency.org/resources/publications/european-agency-statistics-inclusive-education-2018-dataset-cross-country

Ravens-Sieberer, U., Erhart, M., Torsheim, T., Hetland, J., Freeman, J., Danielson, M. og Thomas, C. (2008). HBSC positive health group. An international scoring system for self-reported health complaints in adolescents. European Journal of Public Health, 18(3), 294-299. https://doi.org/10.1093/eurpub/ckn001

Ravens-Sieberer, U., Torsheim, T., Hetland, J., Vollebergh, W., Cavallo, F., Jericek, H., Alikasifoglu, M., Välimaa, R., Ottova, V., Erhart, M. og HBSC Positive Health Focus Group. (2009). Subjective health, symptom load and quality of life of children and adolescents in Europe. International Journal of Public Health, 54(2), 151-159. https://doi.org/10.1007/s00038-009-5406-8

Rose, R. J., Dick, D. M., Viken, R. J., Pulkkinen, L. og Kaprio J. (2001). Drinking or abstaining at age 14? A genetic epidemiological study. Alcohol Clinical and Experimental Research, 25(11), 1594-1604. https://doi. org/10.1111/j.1530-0277.2001.tb02166.x

Ruiz-Hernández, J. A., Moral-Zafra, E., Llor-Esteban, B. og Jiménez-Barbero, J. A. (2018). Influence of parental styles and other psychosocial variables on the development of externalizing behaviors in adolescents: A systematic review. The European Journal of Psychology Applied to Legal Context, 11, 9-21. https://doi. org/10.5093/ejpalc2018a11 
Sawyer, S. M., Azzopardi, P. S., Wickremarathne, D. og Patton, G. C. (2018). The age of adolescence. Lancet Child \& Adolescent Health, 2(3), 223-228. https://doi.org/10.1016/S2352-4642(18)30022-1

Sigrún Aðalbjarnardóttir. (2019). Lifssögur ungs fólks: Samskipti, áhættuhegðun, styrkleikar. Háskólaútgáfan.

Sigrún Aðalbjarnardóttir og Kristín Lilja Garðarsdóttir. (2004). Depurð ungs fólks og uppeldisaðferðir foreldra: Langtímarannsókn. Sálfraðiritið - Tímarit Sálfraðingafélags Íslands, 9, 151-166.

Sigrún Aðalbjarnardóttir og Leifur G. Hafsteinsson. (2001). Parenting styles and adolescent substance use: A longitudinal study. Journal of Research on Adolescence, 11(4), 401-423. https://doi.org/10.1111/15327795.00018

Soenens, B., Deci, E. L. og Vansteenkiste, M. (2017). How parents contribute to children's psychological health: The critical role of psychological need support. I M. L. Wehmeyer, K. A. Shogren, T. D. Little og S. J. Lopez (ritstjórar), Development of self-determination through the life-course (bls. 171-187). Springer. https://doi. org/10.1007/978-94-024-1042-6_13

Solmi, M., Radua, J., Olivola, M., Croce, E., Soardo, L., de Pablo, G. S., Shin, J. I., Kirkbride, J. B., Jones, P., Kim, J. H., Kim, J. Y., Carvalho, A. F., Seeman, M. V., Correll, C. U. og Fusar-Poli, P. (2021). Age at onset of mental disorders worldwide: Large-scale meta-analysis of 192 epidemiological studies. Molecular Psychiatry. https://doi.org/10.1038/s41380-021-01161-7

Steinberg, L. (2001). We know some things: Parent-adolescent relationships in retrospect and prospect. Journal of Research on Adolescence, 11(1), 1-19. https://doi.org/10.1111/1532-7795.00001

Veldman, K., Reijneveld, S. A., Ortiz, J. A., Verhulst, F. C. og Bultmann, U. (2015). Mental health trajectories from childhood to young adulthood affect the educational and employment status of young adults: Results from the TRAILS study. Journal of Epidemiology and Community Health, 69(6), 588-593. https:// doi.org/10.1136/jech-2014-204421

WHO. (2017). Global accelerated action for the health of adolescents (AA-HA!): Guidance to support country implementation. http://apps.who.int/iris/bitstream/10665/255415/1/9789241512343-eng.pdf?ua=1

Woods, H. C. og Scott, H. (2016). \#Sleepyteens: Social media use in adolescence is associated with poor sleep quality, anxiety, depression and low self-esteem. Journal of Adolescence, 51, 41-49. https://doi.org/10.1016/j. adolescence.2016.05.008

Ragný Póra Guðjohnsen og Ársæll Arnarsson. (2021).

Vímuefnaneysla ungmenna skoðuð í ljósi líðanar peirra og tengsla við foreldra.

Netla - Veftímarit um uppeldi og menntun: Sérrit 2021 - HBSC og ESPAD rannsóknirnar

Sótt af http://netla.hi.is/serrit/2021/HBSC_ESPAD_rannsoknir/05.pdf

DOI: https://doi.org/10.24270/serritnetla.2021.9 